\title{
PENGARUH TINGKAT KEBISINGAN TERHADAP GANGGUAN PENDENGARAN PADA KARYAWAN PT. ANDIKA PRATAMAM JAYA ABADI, TANJUNG MORAWA KABUPATEN DELI SERDANG TAHUN 2020
}

\author{
Agnes Rya Sianturi ${ }^{1}$, Denico Ivander Tambunan ${ }^{2}$, Dendy Teguh Kurniawan ${ }^{3}$, Masdalena ${ }^{4}$ \\ 1,2,3,4 Program Studi Pendidikan Dokter, Fakultas Kedokteran, Universitas Prima Indonesia \\ Amandadianmawaddah@gmail.com
}

\begin{abstract}
Abstrak
Penelitian ini bertujuan untuk mengetahui pengaruh tingkat kebisingan terhadap gangguan pendengaran. Jenis peneliyian ini adalah kuantitatif yang bersifat analitik observasional yaitu penelitian yang mencoba menggali bagaimana dan mengapa fenomena kesehatan itu terjadi yang kemudian melakukan analisi dinamika korelasi antara faktor resiko dan faktor efek dengan menggunakan pendekatan cross sectional yaitu peneliti melakukan observasi atau pengukuran variabel subyek hanya diobservasi satu kali dan pengukuran variabel dilakukan pada saat pemeriksaan tersebut. Populasi dalam penelitian ini adalah seluruh karyawan PT. Andhika Pratama Jaya Abadi, Tanjung Morawa, Deli Serdang yang berjumlah 40 orang pekerja yang melakukan pekerjaan dalam 1 shift. Hasil penelitian dengan menggunakan uji chi-square didapati bahwa pengaruh kebisingan di area kerja dengan kejadian gangguan pendengaran di PT Andhika Pratama Jaya Abadi menunjukkan ada pengaruh yang bermakna antara tingkat kebisingan di area kerja dengan kejadian gangguan pendengaran dengan perolehan $\mathrm{p}=0,012$ sehingga sehingga $\mathrm{HO}$ diterima dan $\mathrm{Ha}$ ditolak, yang berarti terdapat pengaruh antara kebisingan di area kerja dengan kejadian gangguan pendengaran. Hasil analisis dengan menggunakan uji chi-square didapati bahwa pengaruh penggunaan APT dengan kejadian gangguan pendengaran di PT Andhika Pratama Jaya Abadi menunjukkan ada pengaruh yang bermakna antara lama bekerja dengan kejadian gangguan pendengaran dengan perolehan $\mathrm{p}=0,000$ sehingga sehingga $\mathrm{HO}$ diterima dan $\mathrm{Ha}$ ditolak, yang berarti terdapat pengaruh antara penggunaan APT dengan kejadian gangguan pendengaran.
\end{abstract}

Kata Kunci : Tingkat Kebisingan, Durasi Paparan Kebisingan, Pemakaian APD, Gangguang pendengaran

\begin{abstract}
This study aims to determine the effect of noise levels on hearing loss. This type of research is quantitative with observational analytic nature, namely research that tries to explore how and why the health phenomenon occurs which then analyzes the dynamics of the correlation between risk factors and effect factors using a cross sectional approach, in which the researcher observes or measures the subject variable only once observed. and variable measurements are made at the time of the examination. The population in this study were all employees of PT. Andhika Pratama Jaya Abadi, Tanjung Morawa, Deli Serdang, totaling 40 workers who work in 1 shift. The results of the study using the chi-square test found that the effect of noise in the work area with the incidence of hearing loss at PT Andhika Pratama Jaya Abadi shows that there is a significant effect between the level of noise in the work area and the incidence of hearing loss with the acquisition of $p=0.012$ so that $\mathrm{HO}$ is accepted and $\mathrm{Ha}$ is rejected, which means that there is an influence between noise in the work area and the incidence of hearing loss. The results of the analysis using the chi-square test found that the effect of using APT with the incidence of hearing loss at PT Andhika Pratama Jaya Abadi shows that there is a significant effect between the length of work and the incidence of hearing loss with the acquisition of $\mathrm{p}=0,000$ so that $\mathrm{HO}$ is accepted and $\mathrm{Ha}$ is rejected, which means there is an influence between the use of APT with the incidence of hearing loss.
\end{abstract}

Keywords: Noise Level, Duration of Noise Exposure, Use of PPE, Hearing Disturbance 


\section{PENDAHULUAN}

World Health Organisation (WHO) menyatakan pada tahun 2014 terdapat 360 juta orang didunia mengalami gangguan pendengaran akibat paparan terhadap tingkat kebisingan yang tinggi, dimana ditemukan 328 juta (91\%) orang dewasa dan 32 juta (9\%) adalah anakanak(Bickenbach, 2018). Menurut data WHO pada tahun 2007, Indonesia merupakan salah satu negara Asia Tenggara yang mengalami prevalensi gangguan pendengaran yang cukup tinggi yaitu mencapai 4,2\% akibat terpapar lama dengan kebisingan ${ }^{1}$

Kebisingan menjadi salah satu masalah yang sering ditemukan dalam lingkungan kerja (D.Bagian, 2019). Kebisingan diartikan sebagai bunyi ataupun suara yang tidak dikehendaki dan sangat mengganggu serta membahayakan tenaga kerja . Sumber bising dapat berasal dari proses penggunaan alat-alat produksi ataupun mesin untuk menjalankan proses produksinya (efek sektor industri).Jika terpapar terus-menerus dengan kebisingan akan sangat berpengaruh bagi kesehatan. Pengaruh yang ditimbulkan salah satunya adalah gangguan pendengaran yang dapat bersifat sementara ataupun menetap ${ }^{2}$.

Gangguan Pendengaran akibat kebisingan atau disebut Noice Induce Hearing Loss (NIHL) memiliki resiko tinggi bagi pekerja yang terpapar lama pada tingkat kebisingan yang tinggi pula ${ }^{3}$. Adapun beberapa faktor yang mempengaruhi gangguan pendengaran yaitu umur pekerja, masa kerja, riwayat gangguan pendengaran sebelumnya, dan tidak menggunakan alat pelindung dirit ${ }^{4-5}$.

Menteri Tenaga Kerja Republik Indonesia menetapkan Nilai Ambang Batas (NAB) menjadi standar faktor bahaya di Tempat Kerja sebagaimana kadar/intensitas rata-rata tertimbang waktu (time weighted averege) ditempat kerja yang dapat diterima Tenaga Kerja tanpa mengakibatkan penyakit atau gangguan kesehatan, dalam pekerjaan sehari-hari untuk waktu tidak melebihi 8 jam sehari atau 40 jam seminggu ${ }^{6}$

Menurut penelitian yang pernah dilakakukan sebelumnya, ada beberapa hasil penelitian yang menyatakan adanya pengaruh tingkat kebisingan dengan gangguan pendengaran, diantaranya adalah penelitian yang dilakukan M.Arif (2016) terdapat 67 orang $(97,1 \%)$ dari 128 responden mengalami gangguan pendengaran akibat tingkat kebisingan di PLTD Sungguminasa. Hasil penelitian yang dilakukan (Adnyani \& Adiputra 2017) menjelaskan dari 36 reponden terdapat 10 orang yang mengalami gangguan pendengaran dari ringan sampai berat akibat paparan kebisingan pada Pekerja kayu di
Desa Mas Kecamatan Ubud Kabupaten Gianyar. Penelitian ini juga menjelaskan bahwa usia dan lama kerja menjadi faktor resiko mempercepat gangguan fungsi pendengaran. Berdasarkan penelitian yang telah dilakukan (D.Bagian 2019) dapat ditarik kesimpulan yaitu terdapat hubungan antara tingkat kebisingan yang diikuti dengan faktor umur dan pemakaian APD serta perilaku merokok dengan kejadian gangguan pendengaran pada pekerja dibagian produksi PT. Adi Setia Abadi, Yogyakarta ${ }^{7,8}$

PT. Andhika Pratama Jaya Abadi (PT. APJA) merupakan suatu perusahaan yang bergerak dibidang konstruksi pabrikasi dan pemasangan mekanikal dan civil pembangunan pabrik minyak kelapa sawit. Permasalahan yang ditemukan pada perusahaan ini ialah adanya kebisingan yang timbul pada daerah Workshop (titik tempat yang memiliki tingkat kebisingan cukup tinggi). Kebisingan terutama terjadi pada waktu proses melakukan penggerindaan, pengoprasian gerinda, pengoprasian mesin bubut, dan lain sebagainya.

Belum ada survei mendalam mengenai kebisingan ditempat kerja tersebut apakah sudah melebihi Nilai Ambang Batas (NAB) yang diperkenankan (85 dBA untuk 8 jam kerja) dalam peraturan Menteri Tenaga Kerja dan Transmigrasi Republik Indonesia. belum ada survei mendalam mengenai data pekerja yang mengalami gangguan pendengaran akibat kebisingan di perusahaan tersebut ${ }^{9,10}$

Dari uraian diatas penelitian ini dilakukan untuk mengetahui pengaruh tingkat kebisingan terhadap gangguan pendengaran pada karyawan PT. Andhika Pratama Jaya Abadi, Tanjung Morawa Kabupaten Deli Serdang.

\section{METODE}

Penelitian ini menggunakan jenis penelitian Kuantitatif yang berdifat analitik observasional yaitu penelitian yang mencoba menggali bagaimana dan mengapa fenomena kesehatan itu terjadi yang kemudian melakukan analisis dinamika korelasi antara faktor resiko dan faktor efek. Berdasarkan pendekatannya, penelitian ini menggunakan pendekatan Cross Sectional yaitu peneliti melakukan observasi atau pengukuran variabel subyek hanya diobservasi satu kali dan pengukuran variabel dilakukan pada saat pemeriksaan tersebut.

\section{Lokasi dan Waktu}

Penelitian ini dilaksanakan di PT. Andhika Pratama Jaya Abadi, Tanjung Morawa, Kabupaten Deli Serdang Morawa, Deli Serdang. 


\section{Sampel Penelitian}

Sampel ialah sebagian kecil populasi yang digunakan dalam uji untuk memperoleh informasi statistik mengebai keseluruhan populasi. Teknik pengambilan sampel dalam penelitian ini menggunakan teknik Nonprobability yaitu sampel jenuh atau sering disebuttotal sampling. Total sampling adalah teknik pengambilan sampel dimana jumlah sampel sama dengan jumlah populasi Alasan mengambil total sampling karena menurut Sugiyono jumlah populasi yang kurang dari 100, seluruh populasi dijadikan sampel penelitian semuanya. Sampel yang diambil dari penelitian ini 40 orang pekerja ${ }^{(9)}$.

\section{Metode Pengumpulan Data}

Data yang digunakan pada penelitian ini adalah data primer, yaitu data yang dihimpun oleh peneliti langsung. Data durasi paparan dan penggunaan alat pelindung diri diperoleh dari pengisian kuesioner oleh pekerja. Data tingkat kebisingan diperoleh dari pengukuran dengan menggunakan alat Sound Level Meter. Data gangguan pendengaran diperoleh dari pengukuran menggunakan alat audiometer.

\section{Instrumen Penelitian}

Instrumen penelitian adalah alat yang digunakan dalam penelitian untuk memperoleh data, dalam penelitian ini instrumen yang digunakan adalah:

1. Lembar Informed Consent

2. Kuesioner Penelitian

3. Sound Level Meter

Langkah-Langkah Penelitian

1. Tahap Persiapan

a. Menghidupkan Sound Level Meter

b. Menyesuaikan pembobotan waktu respon alat ukur dengan karakteristik sumber bunyi yang diukur

2. Tahap Pelaksanaan

a. Memegang Sound Level Meter tegak lurus dengan arah angin

b. Jarak Sound Level Meter 1 meter dari sumber kebisingan.

c. Alat diletakkan setinggi telinga menghadap sumber bising

d. Menghidupkan Sound Level Meter

e. Membaca nilai dB maksimal, minimal dan Leq yang tertera pada Sound Level Meter

f. Setelah itu mencatat dan mengkategorikan menjadi $\leq 85 \mathrm{~dB}$ atau $\geq 85 \mathrm{~dB}$.

Pengambilan tingkat kebisingan

dilaksanakan mengguanakan cara sederhana sesuai Keputusan Menteri Negara Lingkungan Hidup Nomor Kep-48/MENLH/11/1996 tentang baku tingkatan kebisingan. Cara ini dilakukan menggunakan Sound Level Meter dengan mengukur tingkat tekanan

bunyi $(\mathrm{dB})$ selama 10 menit untuk tiap pengukuran satu lokasi kerja dan pembacaan dilakukan setiap 5 detik.

\section{HASIL \\ Pengaruh Kebisingan Area Kerja dengan Gangguan Pendengaran}

Hasil analisis dengan menggunakan uji chisquare didapati bahwa pengaruh kebisingan di area kerja dengan kejadian gangguan pendengaran di PT Andhika Pratama Jaya Abadi menunjukkan ada pengaruh yang bermakna antara tingkat kebisingan di area kerja dengan kejadian gangguan pendengaran dengan perolehan $\mathrm{p}=0,012$ sehingga sehingga $\mathrm{HO}$ diterima dan $\mathrm{Ha}$ ditolak, yang berarti terdapat pengaruh antara kebisingan di area kerja dengan kejadian gangguan pendengaran.

Hasil penelitian ini sejalan dengan hasil penelitian Harmadji dan Kabullah (2004) yang berjudul Intensitas kebisingan dan gangguan pendengaran. Penelitian yang dilakukan pada pabrik baja desa Janti Sidoarjo Jawa Tengah (2004) menunjukan hubungan yang signifikan antara tingkat kebisingan dengan kejadian kehilangan pendengaran akibat bising ${ }^{(9)}$.

Gangguan pendengaran diakibatkan oleh rusaknya telinga dalam baik berupa kerusakan sel rambut ataupun kerusakan total organ korti. Telinga denganpaparan bising melebihi ambang batas dan intensitas yang sering, mengakibatkan perubahan metabolik dan vaskuler yang berdampak pada perubahan degeneratif dalam bentuk sensorik. Selsel sensorik yang terpajan akan mengalami peningkatan metabolisme, diikuti oleh peningkatan endoplasma vestibulum. Hal tersebut mengakibatkan pembengkakan dan perobekan pada sel. Selanjutnya kerusakan irreversibel sel

rambut karena adanya penggunaan $\mathrm{O} 2$ secara berlebih oleh sel-sel sensoris yang terpapar bising. Penggunaan $\mathrm{O} 2$ secara berlebih ini mengakibatkan adanya penurunan $\mathrm{O} 2$ pada duktus koklearis.

\section{Pengaruh Lama Bekerja dengan Gangguan Pendengaran}

Hasil analisis dengan menggunakan uji chisquare didapati bahwa pengaruh lama bekerja dengan kejadian gangguan pendengaran di PT Andhika Pratama Jaya Abadi menunjukkan ada pengaruh yang bermakna antara lama bekerja dengan kejadian gangguan pendengaran dengan perolehan $p=0,000$ sehingga sehingga $\mathrm{HO}$ diterima 
dan Ha ditolak, yang berarti terdapat pengaruh antara lama bekerja dengan kejadian gangguan pendengaran dapat dilihat pada tabel 1.

Tabel 1. Hasil Pengukuran Gangguan Pendengaran
Kualanamu ( $p$ value $=0,001)$. Pemakaian alat pelindung telinga (APT) sebagai tindakan preventif untuk mencegah agar gangguan pendengaran tidak semakin parah ${ }^{12}$

\begin{tabular}{|c|c|c|c|c|c|}
\hline \multirow[b]{2}{*}{ Variabel } & \multicolumn{3}{|c|}{ Gangguan Pendengaran } & \multirow[b]{2}{*}{$\begin{array}{l}\text { Total } \\
\mathrm{n}(\%)\end{array}$} & \multirow[b]{2}{*}{ Nilai $p$} \\
\hline & $\begin{array}{c}\text { Normal } \\
\text { n(\%) }\end{array}$ & $\begin{array}{c}\text { Tuli Ringan } \\
\text { n(\%) }\end{array}$ & $\begin{array}{c}\text { Tuli Sedang } \\
\mathrm{n}(\%)\end{array}$ & & \\
\hline \multicolumn{6}{|c|}{ Kebisingan Area Kerja } \\
\hline$-\quad \leq 85 \mathrm{~dB}$ & $16(40)$ & $3(7,5)$ & $0(0)$ & $19(47,5)$ & \multirow{2}{*}{0,012} \\
\hline$-\quad>85 \mathrm{~dB}$ & $9(22,5)$ & $6(15)$ & $6(15)$ & $21(52,5)$ & \\
\hline \multicolumn{6}{|l|}{ Lama Bekerja } \\
\hline$-\quad \leq 8 \mathrm{jam}$ & $16(40)$ & $0(0)$ & $0(0)$ & $16(40)$ & \multirow{2}{*}{0,000} \\
\hline$-\quad>8$ jam & $9(22,5)$ & $9(22,5)$ & $6(15)$ & $24(60)$ & \\
\hline \multicolumn{6}{|l|}{ Penggunaan APT } \\
\hline$-Y a$ & $9(22,5)$ & $9(22,5)$ & $6(15)$ & $24(60)$ & \multirow{2}{*}{0,000} \\
\hline - $\quad$ Tidak & $16(40)$ & $0(0)$ & $0(0)$ & $16(40)$ & \\
\hline
\end{tabular}

Hasil penelitian ini sejalan dengan hasil penelitian Kelly (2012) yang berjudul Daily Noise Exposure Can Lead To Permanent Hearing Loss In Nightclub Bar Employees.Dalam penelitiannya pada pekerja bar klub malam di Leinster, Kelly menyatakan bahwa pekerja dapat terpapar bising hampir empat level melebihi dari batas legal. Kelly menemukan bahwa paparan kebisingan sehari-hari para pekerja (L EX, 8h) rata-rata adalah antara 89 $97 \mathrm{dBA}$, sementara batas normal yang masih diperkenankan adalah 87 dBA. Pada penelitian ini, Kelly menyebutkan bahwa paparan kebisingan lebih dari 85 dBA selama 8 jam per hari dapat menyebabkankehilangan pendengaran permanen selama beberapa tahun paparan ${ }^{11}$

\section{Pengaruh Penggunaan APT dengan Gangguan Pendengaran}

Hasil analisis dengan menggunakan uji chisquare didapati bahwa pengaruh penggunaan APT dengan kejadian gangguan pendengaran di PT Andhika Pratama Jaya Abadi menunjukkan ada pengaruh yang bermakna antara lama bekerja dengan kejadian gangguan pendengaran dengan perolehan $\mathrm{p}=0,000$ sehingga sehingga $\mathrm{HO}$ diterima dan Ha ditolak, yang berarti terdapat pengaruh antara penggunaan APT dengan kejadian gangguan pendengaran.

Hasil penelitian ini sejalan dengan hasil penelitian Ramadhani (2018) yang berjudul Pemakaian APT dengan Gangguan Pendengaran Pekerja Ground Handling di Bandara Kualanamu. Penelitian inimendapatkan bahwa ada hubungan antara pemakaian alat pelindung diri dengan gangguan pendengaran pada pekerja bagian ground handling di Bandara Internasional
Pemakaian APD khususnya APT merupakan cara terakhir yang harus dilakukan untuk melakukan pengendalian terhadap sumber bahaya (bising), sehingga dapat mampu mengurangi dampak dari kebisingan di tempat kerja. Daerah utama kerusakan akibat kebisingan pada manusia adalah pendengaran (telinga bagian dalam), maka metode pengendaliannya dengan memanfaatkan alat bantu dengar yang bisa mereduksi tingkat kebisingan yang masuk ke telinga bagian luar dan bagian tengah sebelum masuk ke telinga bagian dalam ${ }^{13}$

\section{SIMPULAN}

Berdasarkan hasail penelitian yang dilakukan di PT Andhika Pratama Jaya Abadi terhadap 40 orang responden dapat disimpulkan beberapa hal berikut ini :

1. Terdapat pengaruh antara kebisingan di area kerja dengan kejadian gangguan pendengaran dengan perolehan uji chi-square $=0,012$.

2. Terdapat pengaruh antara lama bekerja dengan kejadian gangguan pendengaran dengan perolehan uji chi-square $=0,000$.

3. Terdapat pengaruh antara penggunaan APT dengan kejadian gangguan pendengaran dengan perolehan uji chi-square $=0,000$.

\section{SARAN}

Saran yang dapat diberikan penulis dalam penelitian ini adalah sebagai berikut: 
1. Bagi PT Andhika Pratama Jaya Abadi Diharapkan untuk selalu melakukan pengecekan audiometri rutin untuk mengecek kesehatan pendengaran para pekerja dan mengikuti Peraturan yang berlaku tentang tingkat kebisingan yang diperbolehkan sehingga bisa mengurangi jumlah gangguan pendengaran

2. Bagi Peneliti Selanjutnya Perlu dilakukan penelitian yang lebih lanjut untuk mengetahui faktor - faktor yang mempengaruhi gangguan pendengaran pekerja selain variabel yang diuji dalam penelitian ini.

\section{DAFTAR PUSTAKA}

1. Jayanti S, Suwondo A, Marlina S. Analisis Faktor Risiko Gangguan Pendengaran Sensorineural Pada Pekerja Pt. X Semarang. J Kesehat Masy. 2016;4(1):359-66.

2. Adnyani AL, Adiputra LMISH. Prevalensi Gangguan Fungsi Pendengaran Akibat Kebisingan Lingkungan Kerja pada Pekerja Kayu di Desa Mas Kecamatan Ubud Kabupaten Gianyar. E-Journal Med Udayana. 2017;6(12):144-7.

3. Wardhani DK, Mukono JM. Sensorineural Hearing Loss Due to Exposure of Noisy Trains on Populations Around Turirejo Train Railroad Cross. J Kesehat Lingkung. 2020;12(1):59.

4. Kurnia M, Isya M, Zaki M. TINGKAT KEBISINGAN YANG DIHASILKAN DARI AKTIVITAS TRANSPORTASI ( STUDI KASUS PADA SEBAGIAN RUAS JALAN : MANEK ROO, SISINGAMANGARAJA DAN GAJAH MADA. 2018;1(2):1-9.

5. Irawati L, Fisika B, Fakultas K, Universitas K. Fisika medik proses pendengaran. 2012;36:15562.

6. Ketenagakerjaan PM, Indonesia R, Dan K, Kerja $K$, Kerja L, Rahmat D, et al. BERITA NEGARA. 2018;(567).

7. Sayidah P, Sekarwati N, Indriyani DW. Pengaruh Kebisingan Dengan Gangguan Pendengaran Di Dusun Jagalan Tegaltirto Berbah Sleman. MIKKI (Majalah IImu Keperawatan dan Kesehat Indones [Internet]. 2016;4(1):198-204. Available from: https://jurnal.stikeswirahusada.ac.id/index.php/mikki/article/view/ 111

8. Arif MI. Pengaruh Akibat Kebisingan Terhadap Kejadian Gangguan Pendengaran Pada Karyawan Pltd Sungguminasa. J Ilm Kesehat Diagnosis [Internet]. 2016;8(1):82-5. Available from:

http://ejournal.stikesnh.ac.id/index.php/jikd/art icle/view/221

9. Jayanti $K P$, Rudijanto $H$, Abdullah $S$, Lingkungan JK, Kesehatan P, Semarang K, et al. Dengan Keluhan Pendengaran Pekerja Finishing Pt . Pundi Indokayu Industri Kecamatan Kalibagor Kabupaten Banyumas Tahun 2016. 2016;37(1):40-6.

10. Imanto $\mathrm{M}$, Kedokteran $\mathrm{F}$, Lampung U. Radang telinga luar. 2015;201-10.

11. Brown $A L$, van Kamp I. WHO environmental noise guidelines for the European region: A systematic review of transport noise interventions and their impacts on health. Int J Environ Res Public Health. 2017;14(8):1-44.

12. Eryani YM, Wibowo CA, Saftarina F, Kedokteran F, Lampung U, IImu B, et al. Faktor Risiko Terjadinya Gangguan Pendengaran Akibat Bising Risk factors Occurrence of Noise Induce Hearing Loss. 2017;7(November):1127.

13. Unit T, Tahun M, Ibrahim H, Basri S, Hamzah Z. FAKTOR - FAKTOR YANG BERHUBUNGAN DENGAN KELUHAN GANGGUAN PENDENGARAN PADA TENAGA KERJA BAGIAN PRODUKSI PT . JAPFA COMFEED. 2016;8:12134. 